\title{
Modulation of emission properties of phosphine-sulfonate ligand containing copper complexes: playing with solvato-, thermo-, and mechanochromism
} Antoine Vacher, Anissa Amar, Franck Camerel, Yann Molard, Camille Latouche, Thierry Roisnel, Vincent Dorcet, Abdou Boucekkine, Huriye Akdas-Kiliç, Mathieu Achard

\section{To cite this version:}

Antoine Vacher, Anissa Amar, Franck Camerel, Yann Molard, Camille Latouche, et al.. Modulation of emission properties of phosphine-sulfonate ligand containing copper complexes: playing with solvato, thermo-, and mechanochromism. Dalton Transactions, Royal Society of Chemistry, 2019, 48 (6), pp.2128-2134. <10.1039/C8DT04502J>. <hal-02045685>

\section{HAL Id: hal-02045685 \\ https://hal.archives-ouvertes.fr/hal-02045685}

Submitted on 5 Mar 2019

HAL is a multi-disciplinary open access archive for the deposit and dissemination of scientific research documents, whether they are published or not. The documents may come from teaching and research institutions in France or abroad, or from public or private research centers.
L'archive ouverte pluridisciplinaire HAL, est destinée au dépôt et à la diffusion de documents scientifiques de niveau recherche, publiés ou non, émanant des établissements d'enseignement et de recherche français ou étrangers, des laboratoires publics ou privés. 


\title{
Modulation of phosphine sulfonate ligands containing copper complexes emission properties: playing with solvato-, thermo-, and mechanochromism
}

\author{
Antoine Vacher, ${ }^{a}$ Anissa Amar, ${ }^{b}$ Franck Camerel, ${ }^{a}$ Yann Molard, ${ }^{\text {a }}$ Camille Latouche, ${ }^{c}$ Thierry Roisnel, ${ }^{\text {a }}$ Vincent Dorcet, ${ }^{\text {a }}$ Abdou \\ Boucekkine, ${ }^{a^{*}}$ Huriye Akdas-Kiliç ${ }^{a^{*}}$ and Mathieu Achard ${ }^{a^{*}}$ \\ Modulations of various neutral phosphine containing copper(I) complexes exhibiting phosphorescence and TADF are easily achieved by \\ solvent modification restricting intramolecular rotation or by modifying the L-X phosphine-sulfonate chelate. This concept is not limited \\ to solvent as the addition of metallic salts also led to the formation of original well-defined photoluminescent $\mathrm{K}_{2} \mathrm{CuLX}_{3}$ and $\mathrm{KCuL}_{2} \mathrm{X}_{2}$ cuprate \\ complexes.
}

\section{Introduction}

Since the seminal independent observations of Boudin ${ }^{[1 \mathrm{a}]}$ on eosin and Lewis ${ }^{[1 b]}$ on fluorescein of a second long-lived luminescence in viscous/rigid media, delayed fluorescence has attracted a lot of interests. This temperature dependent phenomenon is not limited to organic molecules and reexamination of this concept by McMillin with well-defined copper complexes demonstrated that the emission processes arise from the two close $S_{1}$ and $T_{1}$ excited states leading to the so-called Thermally Activated Delayed Fluorescence (TADF), thus allowing the development of organic and inorganic materials to harvest both singlet and triplet excitons. ${ }^{[2,3,1 \mathrm{~d}]}$ Owing to their possible application in OLEDs as sensor and due to the low cost and abundancy of first row transition metal complexes, copper complexes exhibiting TADF and/or phosphorescence have received a lot of interest as promising alternatives to triplet harvesters based on precious metals. ${ }^{[4,5]}$ Thus, lots of attention has been paid to a careful design of various cationic and neutral mono-, di- and multi-nuclear cuprous complexes to tune their photophysical properties and to minimize geometry distortion in the excited state. ${ }^{[2-11]}$ In contrast cuprate complexes have been far less investigated and usually led to halo bridged coordination polymers ${ }^{[12]}$. Noteworthy that due to the side presence of $\mathrm{Cu}(\mathrm{I})$ in copper

\footnotetext{
a. Univ Rennes, Institut des Sciences Chimiques de Rennes-UMR 6226, ScanMatUMS2001, F-35000 Rennes (France).

E-mail : abdou.boucekkine@univ-rennes1.fr; huriye.akdas@univ-rennes1.fr mathieu.achard@univ-rennes1.fr

b. Département de Chimie, Faculté des Sciences, Université Mouloud Mammeri, 15000 Tizi-Ouzou and USTHB, Alger (Algeria)

-Institut des Matériaux Jean Rouxel (IMN), Université de Nantes, CNRS, 2 rue de la

Houssinière, BP 32229, 44322 Nantes (France)
}

perovskite defects, this material exhibit green photoluminescence. ${ }^{[13]}$

In our quest to develop sustainable approaches to obtain efficient and photoresponsive luminescent molecules, ${ }^{[14]}$ in this article, we present the preparation of various original neutral copper(I) and cuprates(I) complexes arising from the treatment of phosphine-benzenesulfonic acids with solvents and metal salts. Photophysical properties of the synthesized complexes are also investigated.

\section{Results and discussions}

Complex Cu-2 (Scheme 1) was easily synthesized from our Cu-1 ${ }^{[14 a]}$ complex after removal of the coordinated methanol molecules under vacuum followed by the addition of acetonitrile. This simple reaction affords colourless crystals of Cu-2 in 76\% isolated yield. Interestingly, whereas X-ray structure determination highlights the formation of a tetracoordinated mononuclear copper(I) complex bearing two acetonitrile ligands along with 2 lattice acetonitrile molecules restricting rotation of one exocyclic $\mathrm{P}-\mathrm{Ph}$ bond (Figure 1 and Figure S3), $\mathrm{NMR}$ analyses in $\mathrm{CD}_{3} \mathrm{CN}$ and cyclic voltammetry demonstrate the presence of a dimer in acetonitrile solution (Figure S1;S2). The nature of the phosphine plays an important role on the formation of the bi- and mono-nuclear species in the solid state. Replacement of the Murray ligand in $\mathbf{C u - 1}$ by the 

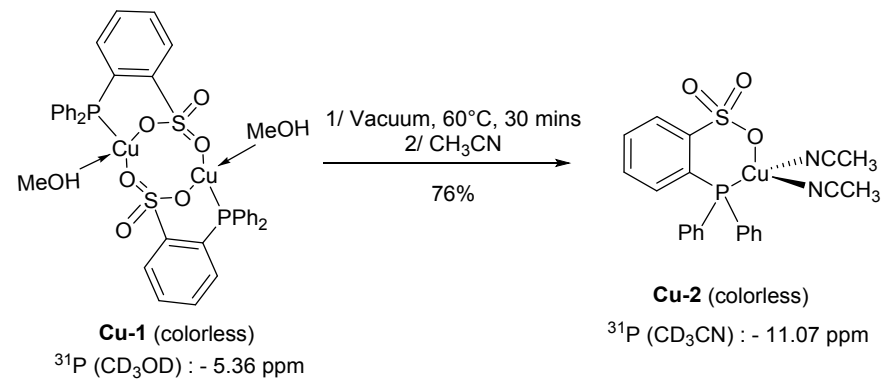

Cu-2 (colorless)

${ }^{31} \mathrm{P}\left(\mathrm{CD}_{3} \mathrm{CN}\right):-11.07 \mathrm{ppm}$

Scheme 1. Facile access to the acetonitrile containing mononuclear complex Cu-2 from the methanol containing dimer $\mathbf{C u}-\mathbf{1}$.

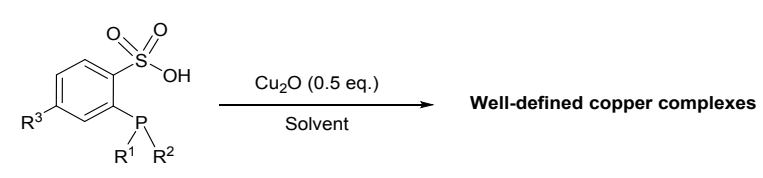

L2-H : $\mathrm{R}^{1}=2-\mathrm{MeOC}_{6} \mathrm{H}_{4} ; \mathrm{R}^{2}=2-\mathrm{MeOC}_{6} \mathrm{H}_{4} ; \mathrm{R}^{3}=\mathrm{H}$

L3-H : $\mathrm{R}^{1}=\mathrm{C}_{6} \mathrm{H}_{5} ; \mathrm{R}^{2}=t-\mathrm{Bu} ; \mathrm{R}^{3}=\mathrm{Me}$

L4-H : $\mathrm{R}^{1}=\mathrm{C}_{6} \mathrm{H}_{5} ; \mathrm{R}^{2}=t-\mathrm{Bu} ; \mathrm{R}^{3}=\mathrm{H}$

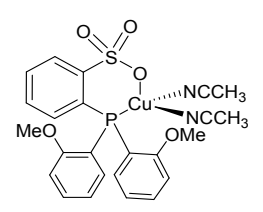

Cu-3 (colorless)

${ }^{31} \mathrm{P}\left(\mathrm{CD}_{3} \mathrm{CN}\right):-27.8 \mathrm{ppm}$

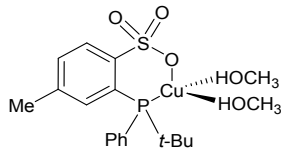

Cu-4 (colorless)

${ }^{31} \mathrm{P}\left(\mathrm{CD}_{3} \mathrm{OD}\right):-14.15 \mathrm{ppm}$

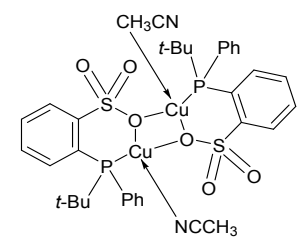

Cu-5 (colorless)

${ }^{31} \mathrm{P}\left(\mathrm{CD}_{3} \mathrm{CN}\right): 8.06 \mathrm{ppm}$
Scheme 2. Impact of the chelate and solvent on nuclearity.

sterically hindered Drent ligand $\mathbf{L 2}-\mathbf{H}^{[15]}$ (Scheme 2) known to shield the metallic centre resulted in the formation of an unstable species in methanol. In contrast to this result, when the reaction was conducted in acetonitrile moderately stable Cu-3 was isolated as a mononuclear complex. Interestingly, when the reaction was carried out with our previously $t$-Bu based phosphine-sulfonate precursor $\mathbf{L} 4-\mathbf{H},{ }^{[16]}$ we were able to isolate a dinuclear copper(I) complex where the coordinated oxygen atoms play the role of bridging ligands to form a diamond core four membered metallacycle $\mathbf{C u}-\mathbf{5}$ reminiscent to the observation of a dimer form from $\mathbf{C u}-\mathbf{2}$ in acetonitrile. The crystal structures for all the synthesized complexes confirm the crucial pyramidal trigonal planar geometry on the copper metallic centres (Figure 1). ${ }^{[17,18]}$ The synthesized colourless complexes exhibit photoluminescence in the solid state (Table 1). The spectrum envelopes are broad and featureless for complexes from $\mathbf{C u}-\mathbf{1}$ to $\mathbf{C u}-\mathbf{5}$ at room temperature and consistent with emission from the ${ }^{3} \mathrm{MLCT}$ state. We observed that the emission bands of complexes containing acetonitrile
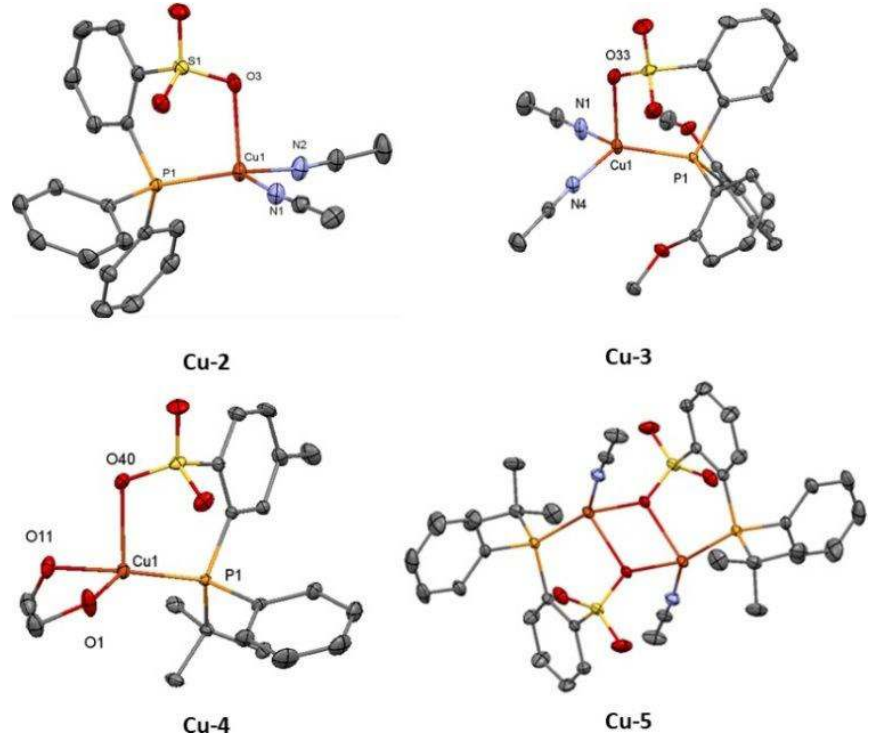

Figure 1. X-ray structures of $\mathbf{C u}-2.2 \mathrm{CH}_{3} \mathrm{CN}$; $\mathbf{C u}-3.1 \mathrm{CH}_{3} \mathrm{CN}$; $\mathbf{C u}-4 ; \mathbf{C u}-5$. lattice solvent molecules and hydrogens have been omitted for clarity. CCDC 1857809, CCDC 1857826, CCDC 1857827 and CCDC 1857812 contain the supplementary crystallographic data for $\mathbf{C u}-\mathbf{2}, \mathbf{C u}-3, \mathbf{C u}-4$ and $\mathbf{C u}-\mathbf{5}$.

ligands are broader and occur in the yellow region, whereas the methanol containing complexes emit in the blue-green area (Table 1). Compared to the complexes $\mathbf{C u - 1 , ~ C u - 2}$ and $\mathbf{C u}-\mathbf{3}$ featuring aryl phosphine-sulfonate chelates, the alkyl phosphine-sulfonate containing complexes $\mathbf{C u}-\mathbf{4}$ and $\mathbf{C u}-\mathbf{5}$ afforded lower emission quantum yield. Notably, the flat dinuclear $\mathbf{C u - 5}$ species with the shortest $\mathrm{Cu}-\mathrm{Cu}$ distance (3.34 $\AA$ ) where $\pi-\pi$ stacking interaction occurs between the MeCN ligand and the $\mathrm{Ar}-\mathrm{SO}_{3}$ moiety letting the exocyclic $\mathrm{P}-\mathrm{C}$ bonds unrestricted led to the weakest emissive complex with a dual emission presumably arising from ${ }^{3} \mathrm{MLCT}$ and ${ }^{3} \mathrm{CC}$ excited states or a vibronic fine structure from a single excited state (Table 1). ${ }^{[10 c, 19]}$ The presence of both solvent lattice and ligand in the corresponding structures suggests reduced vibrational quenching and prevents structural relaxation upon excitation. DFT computations have been performed using the B3PW91 functional[20-22] together with the LANL2DZ basis set [23] augmented with polarization functions using the gaussian09 program. ${ }^{[24]}$ Solvent effects $(\mathrm{MeOH})$ were considered using implicit solvent (PCM) ${ }^{[25]}$ together with explicit molecules in the calculations. The frontier MOs of the complex $\mathbf{C u - 1}$ are depicted in Figure 2. 


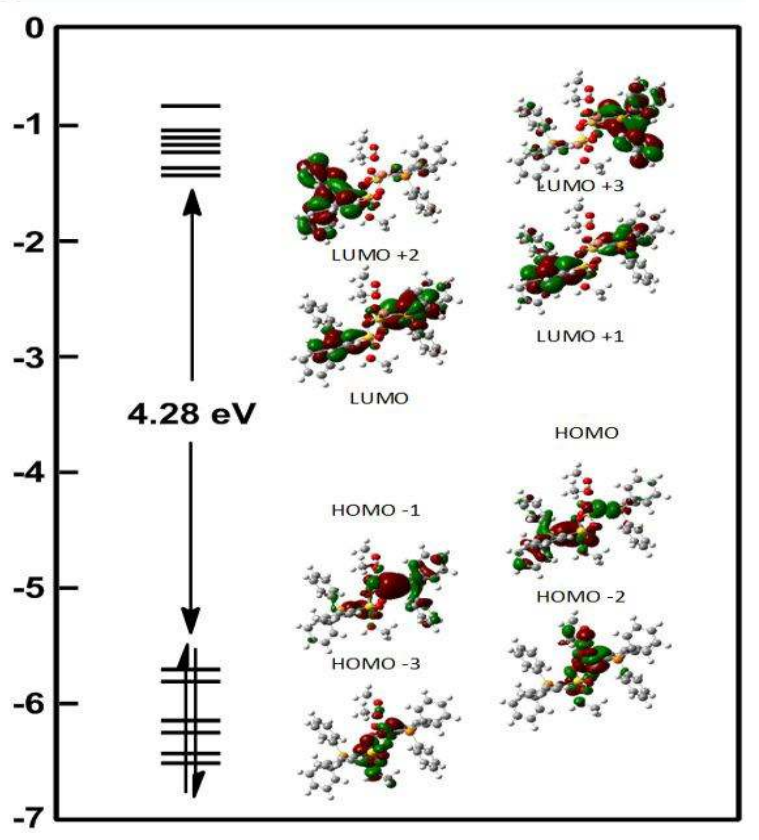

Figure 2: frontier MO diagram of complex Cu-1.

The HOMO and HOMO-1, which are very close in energy (-5.96 vs. $-5.88 \mathrm{eV})$, are rather similar and exhibit a strong $3 d$ orbital metallic character $(>52 \%)$ as well as HOMO-2 and HOMO-3. On the opposite, the LUMO and LUMO +1 , which are also quasidegenerate, are clearly localized on the $\mathrm{P}-\mathrm{Ph}_{3}$ moieties.

Considering the UV-vis spectra, compound Cu-1 exhibits an absorption in solution (MeOH) at $260 \mathrm{~nm}$. In Table 2, are given the results of the TD-DFT computations of its electronic spectrum, namely the wavelengths and oscillator strengths as well as the transitions involved in the excitations, using the B3PW91 functional and the CAM-B3LYP one. ${ }^{[25-26]}$ As it can be

Table 1 Experimental and calculated optical data.

\begin{tabular}{|c|c|c|c|c|c|c|c|c|c|c|}
\hline \multirow{2}{*}{ Complex } & \multirow{2}{*}{$\lambda_{\mathrm{abs}}(\mathrm{nm})^{\mathrm{a}}$} & \multicolumn{2}{|c|}{$\lambda_{\mathrm{em}}(\mathrm{nm})$} & \multirow{2}{*}{$\Phi^{\mathrm{b}}$} & \multicolumn{2}{|c|}{$\tau(\mu \mathrm{s})^{\mathrm{c}}$} & \multirow{2}{*}{$k_{r}(298 \mathrm{~K})\left[\mathrm{s}^{-1}\right]$} & \multirow{2}{*}{$\tau\left(T_{1}\right)[\mu \mathrm{s}]^{\mathrm{d}}$} & \multirow{2}{*}{$\tau\left(S_{1}\right)[\mu s]^{d}$} & \multirow{2}{*}{$\Delta E_{(\mathrm{S} 1-\mathrm{T} 1)}[\mathrm{eV}]$} \\
\hline & & $78 \mathrm{~K}$ & $298 K$ & & $78 \mathrm{~K}$ & $298 \mathrm{~K}$ & & & & \\
\hline $\mathrm{Cu}-1$ & $244,290,330$ & 515 & 515 & 0.51 & 57 & $2 ; 9$ (2.99) & $170.10^{3}$ & 59 & 0.139 & 0.05 \\
\hline $\mathrm{Cu}-2$ & & & 568 & 0.34 & & 2.0 & $170.10^{3}$ & & & \\
\hline $\mathrm{Cu}-3$ & & & 550 & 0.40 & & & & & & \\
\hline $\mathrm{Cu}-4$ & & & 522 & 0.12 & & & & & & \\
\hline $\mathrm{Cu}-5$ & 230,280 & & $560 ; 600$ & 0.06 & & & & & & \\
\hline $\mathrm{Cu}-6$ & $262,298,320,362$ & 508 & 515 & 0.60 & 76 & 8 & $75.10^{3}$ & 76 & 0.048 & 0.10 \\
\hline $\mathrm{Cu}-7$ & $262,298,474$ & 593 & 568 & 0.10 & 107 & $1 ; 10(3.0)$ & $33.10^{3}$ & 105 & 0.080 & 0.07 \\
\hline
\end{tabular}

${ }^{a}$ in solid state at $298 \mathrm{~K} .{ }^{b}$ in solid state at $298 \mathrm{~K} .{ }^{c}$ number in parenthesis corresponds to $\tau_{a v}=\left(B_{1} /\left(B_{1}+B_{2}\right)\right) \tau_{1}+\left(B_{2} /\left(B_{1}+B_{2}\right)\right) \tau_{2}$, in which $B_{1}$ and $B_{2}$ are relative amplitude for $\tau_{1}$ and $\tau_{2}$, respectively. ${ }^{d}$ Calculated from the fit of the decay curves with the equation provided in ref. 8 a.

seen in Table 2 the computed absorption wavelength using the CAM-B3LYP functional compares well with the observed one. On the contrary the B3PW91 computation overestimates the absorption wavelength This result is not surprising since the involved transitions are HOMO-1 $\rightarrow$ LUMO and HOMO $\rightarrow$ LUMO+1 which possess a long distance charge transfer MLCT character which are more accurately described by the range separated functional CAM-B3LYP. These HOMO to LUMO transitions are assigned to be metal to ligand charge-transfer (MLCT) confirming the previous assignment and the crucial role of solvent molecules. (vide supra).

Table 2: TD-DFT computed UV-vis in solution (MeOH) of Cu-1. Computed oscillator strengths are given in square brackets.

\begin{tabular}{|c|c|l|}
\hline & $\begin{array}{c}\lambda \text { calc. }(\mathrm{nm}) \\
{[\mathrm{f}]}\end{array}$ & Main transitions (weight) \\
\hline B3PW91 & $339[0.042]$ & $\begin{array}{c}\text { HOMO-1 } \rightarrow \text { LUMO (44\%) } \\
\text { HOMO } \rightarrow \text { LUMO+1 (44\%) }\end{array}$ \\
\hline CAM-B3LYP & $267[0.132]$ & $\begin{array}{c}\text { HOMO } \rightarrow \text { LUMO+1 (42\%) } \\
\text { HOMO-1 } \rightarrow \text { LUMO (41\%) }\end{array}$ \\
\hline
\end{tabular}

Depending on the complex, the presence of uncoordinated solvent molecules in the crystal structure led to mechanosensitive species. While $\mathbf{C u}-\mathbf{1}, \mathbf{C u}-\mathbf{3}$ and $\mathbf{C u}-\mathbf{4}$ (Figure S7) are relatively stable in powder form compared to their crystal forms without any changes in their emission properties at room temperature, complex Cu-2 loses after several minutes its emissivity upon grinding with a red shift of its emission (Figure S3, S4). Elemental analysis of room temperature vacuum dried Cu-2 corroborates dimer formation. Additionally, thermal gravimetric analysis of crystals $\mathbf{C u}-\mathbf{2}$ highlights noticeable mass loss at room temperature within 5 minutes (Figure S5). Interestingly, a slight increase of temperature showed an endothermic phenomenon and a significant $11 \%$ mass loss at $55^{\circ} \mathrm{C}$. Taken together below $65^{\circ} \mathrm{C}, 14 \%$ mass loss suggests the loss of acetonitrile molecules on $\mathbf{C u}-\mathbf{2}$ including one coordinated solvent molecule responsible for the decrease of emissivity. ${ }^{[27]}$ Interestingly, an unexpected phenomenon at $73{ }^{\circ} \mathrm{C}$ shows the additional loss of some acetonitrile ligand on the putative dimer leading to a new bright green emissive species. ${ }^{[27]}$ 
Noteworthy that and in contrast to $\mathbf{C u}-\mathbf{1},{ }^{[14 a]} \mathbf{C u}-\mathbf{3}$ and $\mathbf{C u}-\mathbf{4}$, reversible photoluminescence is not observed with powdered Cu-2 after the addition of small amount of acetonitrile. In fact, redissolution followed by crystallization is required to fully restore $\mathbf{C u - 2}$ luminescent properties. ${ }^{[28]}$

Coordinated solvent molecules on the resulting complexes $\mathbf{C u}$ 1 to Cu-5 allow the development of tunable luminescent complexes which might be useful for sensing of solvent molecules via reversible photoluminescence. ${ }^{[5,14 a, 19,27]}$ The drawback of this concept for other applications lies in the long time stability of some complexes towards slow degradation owing to the loss of solvent molecules. This would lead to the modification of the structural environment around the metallic center increasing vibrational quenching as well as structural distortion upon excitation. One way to solve this issue lies in the rigidification of the molecular scaffold by tailoring the electrostatic forces between the charged copper species and a metallic or an organic salt. Thus, taking advantage on the haloand cyano-cuprate chemistry, $\mathbf{C u - 1}$ was next treated with metal salts. ${ }^{[12]}$ Reaction of $\mathbf{C u - 1}$ with an excess of potassium iodide at room temperature led to the precipitation of the mixed cuprate $\mathrm{A}_{2} \mathrm{MLX}_{3}$ Cu-6 as a dianion in $80 \%$ yield (Scheme 3 ). X-ray structural determination highlights the formation of $\mathbf{C u}-\mathbf{6}$ as a 2D-layered material with a minimal Cu-Cu distance of $6.9 \AA$ (Figure 3, Figure S20). During the reaction of DPPBS L1-K with Cu-1 complex in boiling methanol almost quantitative precipitation of the monoanionic cuprate $\mathrm{AML}_{2} \mathrm{X}_{2} \mathbf{C u}-\mathbf{7}$ was obtained. Importantly, in both cases, the iodides do not play the role of bridging ligands and the photoluminescent properties of Cu-6 and $\mathbf{C u - 7}$ are not sensitive to grinding or drying. For the three-air stable neutral and -ate complexes $\mathbf{C u - 1 ,} \mathbf{C u} \mathbf{- 6}$ and $\mathbf{C u}-$ 7 in their powdered form, the emission lifetime increases around ten times from $298 \mathrm{~K}$ to $78 \mathrm{~K}$ (Table 1 and Figure 4). The long emission lifetimes and high quantum yields exclude prompt fluorescence phenomena. The decay curves are largely monoexponential at 78K (Figure S9, S16, S19). Together with temperature increase, the decay times decrease for the three complexes and become biexponential for dimer $\mathbf{C u - 1}$ and $\mathbf{C u} \mathbf{- 7}$. Noteworthy that the emission spectra for $\mathbf{C u - 1 , ~ C u - 6}$ and $\mathbf{C u - 7}$ were not narrowed upon cooling which tend to exclude energy transfer between $\mathbf{C u - 1}$ dimers or $\mathbf{C u - 6}$ polymer or via other nonradiative processes (Figure 4). ${ }^{[12 c]}$ Whereas emission of $\mathbf{C u}-\mathbf{7}$ was, interestingly, red-shifted upon cooling, equivalent to about $742 \mathrm{~cm}^{-1}(0.09 \mathrm{eV})$ peak to peak, no noticeable modification of the emission wavelength was observed with $\mathrm{Cu}$ 1. Furthermore, one should notice that even a slight blue shift was observed with $\mathbf{C u}$-6. Owing to the slightly low-lying $T_{1}$ triplet state, copper complexes exhibiting TADF are usually characterized by a red shift in emission upon cooling. Nevertheless, similar absence of red shift were reported

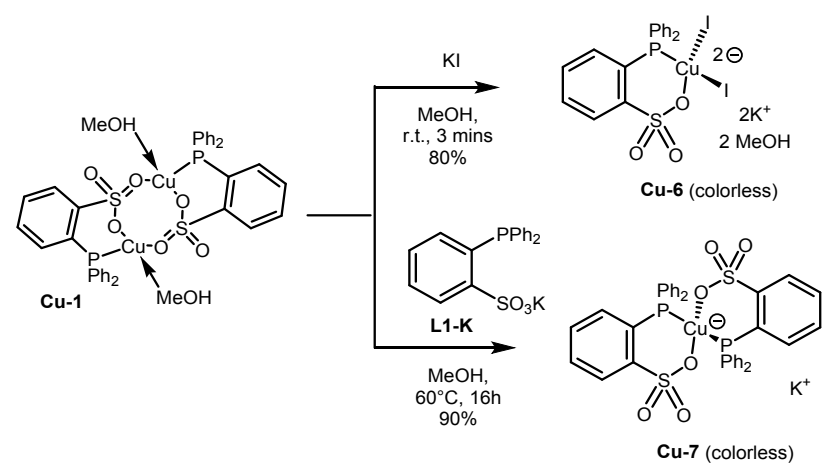

Scheme 3. Preparation of the anionic and dianionic complexes $\mathbf{C u}-\mathbf{7}$ and $\mathrm{Cu}-\mathbf{6}$ from Cu-1.

independently by Osawa and by Yersin, which do not exclude TADF processes. ${ }^{[17,29]}$ Emission decay profile for $\mathbf{C u} \mathbf{- 1}$ suggests that the pure triplet state $\tau\left(\mathrm{T}_{1}\right)$ is reached below $78 \mathrm{~K}$. Small $\Delta$ $E_{S_{1}-T_{1}}$ values were obtained by fitting the sigmoid decay curves which strongly support phosphorescence at low temperature and the occurrence of both phosphorescence and TADF processes upon temperature increase (Table 1). ${ }^{[8]}$ The biexponential decays for $\mathbf{C u} \mathbf{- 1}$ and $\mathbf{C u}-\mathbf{7}$ tends to support these results. The monoexponential decay for Cu-6 suggests essentially overlap due to fast equilibration processes owing to its rigid structure. This could prevent vibrational quenching or deactivation through structural distortion from the tetrahedral to quasi-square-planar coordination geometry (Figure 4). $[17,19,29]$

\section{Conclusions}

In conclusion, we prepared various photoluminescent copper(I) and cuprate(I) complexes by modification of the solvent or the metallic salt with water as the only side product of the overall synthesis. These results pave the way on the preparation of a true library of photoluminescent neutral and anionic complexes by varying the nature of the chelate, the solvent/gas or the metallic salt at the first or second stage of the synthesis to tune their optical properties. The use of other L,X chelating ligands with cuprates might afford interesting materials. Oxidation of the cuprates is underway in our laboratories.

\section{Acknowledgements}

The authors thank the University of Rennes1 for financial support of this project. We acknowledge the HPC resources of CINES and of IDRIS under the allocations 2017 and 2018[x2016080649] made by GENCl. A. B., H. A. K. and M. A. thanks $\mathrm{O}$. Mongin and J. Rocherulle for helpful assistance.

\section{Conflicts of interest}

There are no conflicts of interest to declare 


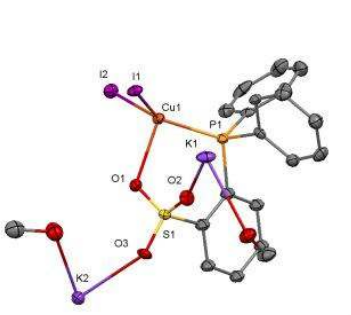

a) 1

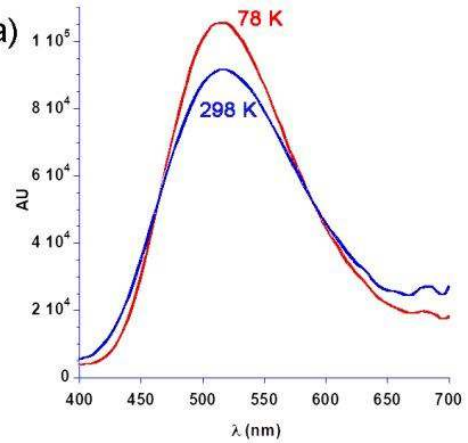

d)

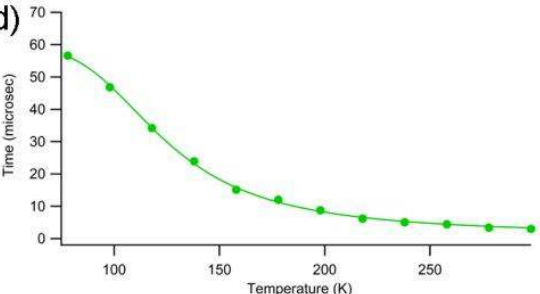

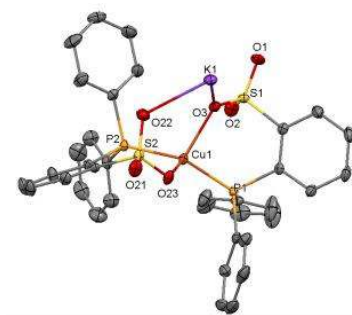

b)
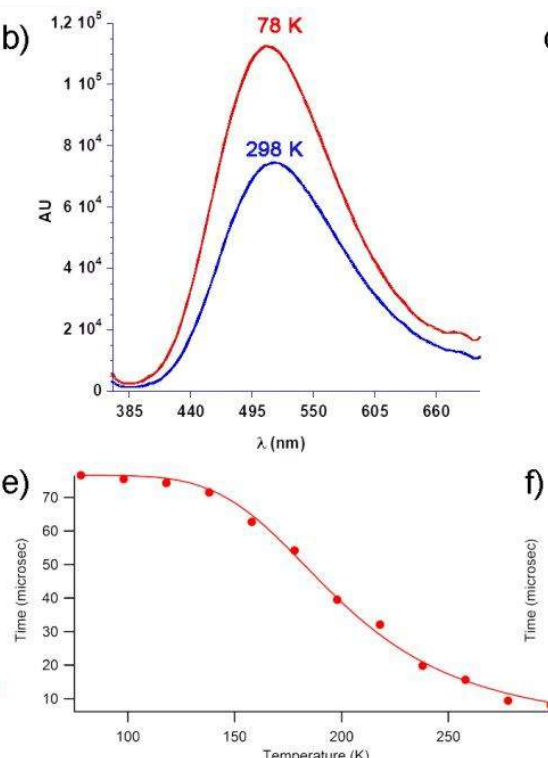

c)
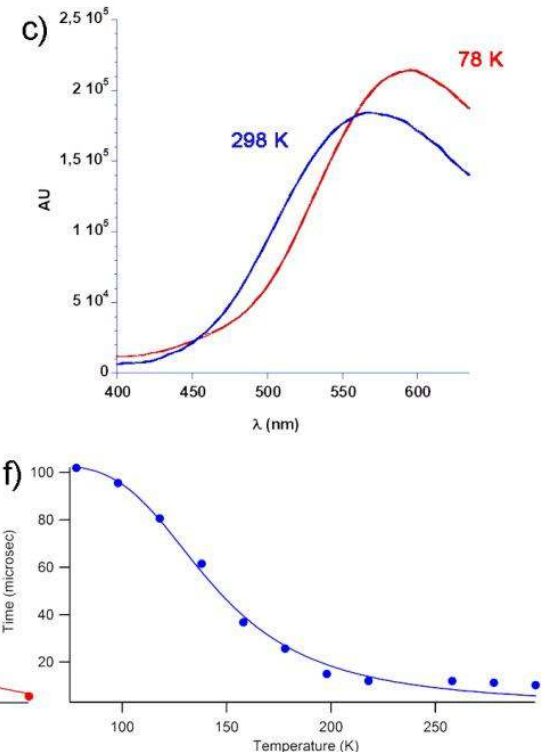

Figure 4. Emission spectra at 78K and 298K of Cu-1 (left), Cu-6 (middle) and Cu-7 (right) and emission decay profiles at different temperatures.

\section{Experimental}

\section{General considerations}

All reactions were carried out under argon atmosphere using Schlenk tube techniques. Unless stated, reagents were purchased from commercial sources and used as received. Acetonitrile, was dried using a MBraun Solvent Purification System. Methanol HPLC grade was degassed and used as received. NMR spectra were recorded at room temperature on a Bruker Avance (400 MHz) spectrometer and reported in ppm. Data are reported as follows: $s=s i n g l e t, d=d o u b l e t, t=t r i p l e t$, $\mathrm{q}=$ quartet, $\mathrm{m}=$ multiplet, $\mathrm{br}=$ broad. Coupling constants are reported in $\mathrm{Hz} .{ }^{13} \mathrm{C}$ NMR spectra were recorded at $100.6 \mathrm{MHz}$ on the same spectrometer and reported in ppm.

\section{Synthesis of $\mathrm{Cu}-2$}

Cu-1 (200 mg, $0.22 \mathrm{mmol}$ ) was added to a Schlenk tube and stirred at $60^{\circ} \mathrm{C}$ under vacuum for 30 mins. The Schlenk was cooled at room temperature followed by the addition of acetonitrile $(4 \mathrm{~mL})$. The resulting mixture was then heated under stirring to dissolve the precipitate. The solution was then cooled at room temperature and then at $-22{ }^{\circ} \mathrm{C}$ to afford colorless crystals of $\mathbf{C u}-\mathbf{2}$. The solution was removed and the crystals of $\mathbf{C u}-2.2 \mathrm{CH}_{3} \mathrm{CN}(190 \mathrm{mg}, 76 \%)$ were kept under argon atmosphere. In contrast to the crystal structure, NMR analyses and cyclic voltammetry support predominance of a dimer in acetonitrile solution. ${ }^{1} \mathrm{H} \mathrm{NMR}\left(400 \mathrm{MHz}, \mathrm{CD}_{3} \mathrm{CN}\right): \delta 8.13-8.05(\mathrm{~m}, 1 \mathrm{H})$, 7.54-7.26 (m, 12H), $7.01(\mathrm{t}, J=7.4 \mathrm{~Hz}, 1 \mathrm{H}), 2.15(\mathrm{~s}, 3 \mathrm{H}) ;{ }^{31} \mathrm{P}\{1 \mathrm{H}\} \mathrm{NMR}$ (162 MHz, CD $\left.{ }_{3} \mathrm{CN}\right):-11.07 ;{ }^{13} \mathrm{C}\{1 \mathrm{H}\}$ NMR $\left(100 \mathrm{MHz}, \mathrm{CD}_{3} \mathrm{CN}\right): \delta 152.1$ $(\mathrm{d}, J=18.5 \mathrm{~Hz}), 135.6$ (s), 134.3, 134.2, 134.0, 131.0, 130.7, 130.5, $129.6(d, J=9.2 \mathrm{~Hz}), 128.6(d, J=5.4 \mathrm{~Hz})$. Elemental analysis for room temperature dried $\mathrm{Cu}-\mathbf{2}-\mathrm{CH}_{3} \mathrm{CN}$, theoretical: $\mathrm{C}, 53.87, \mathrm{H}, 3.84, \mathrm{~N}$, 3.14, S, 7.19, measured: $\mathrm{C}, 53.71, \mathrm{H}, 3.88, \mathrm{~N}, 3.01, \mathrm{~S}, 7.27$.

\section{Synthesis of $\mathrm{Cu}-3$}

Drent ligand 2-\{bis(2-methoxyphenyl)phosphino\}benzenesulphonic acid $\mathbf{~ L 2}-\mathbf{H}\left(135 \mathrm{mg}, 0.33 \mathrm{mmol}\right.$ ) and $\mathrm{Cu}_{2} \mathrm{O}(24 \mathrm{mg}, 0.16 \mathrm{mmol})$ were added in a Schlenk tube under an atmosphere of argon followed by the slow addition of degassed acetonitrile under stirring. Then, the resulting mixture was stirred for one hour at room temperature. The white precipitate was dissolved by the addition of extra acetonitrile followed by cannulation and concentration to afford colorless crystals of Cu-3 (73 mg, 40\%). ${ }^{1} \mathrm{H}$ NMR ( $400 \mathrm{MHz}, \mathrm{CD}_{3} \mathrm{CN}$ ): $\delta 8.10$ (ddd, $J=7.8,4.7,1.4 \mathrm{~Hz}, 1 \mathrm{H}), 7.51-7.44(\mathrm{~m}, 3 \mathrm{H}), 7.30(\mathrm{td}, J=7.6,1.4 \mathrm{~Hz}, 1 \mathrm{H})$, $7.03(\mathrm{dd}, J=8.3,5.2 \mathrm{~Hz}, 2 \mathrm{H}), 6.97-6.88(\mathrm{~m}, 3 \mathrm{H}), 6.71(\mathrm{t}, J=8.5 \mathrm{~Hz}, 2 \mathrm{H})$, $3.68(\mathrm{~s}, 6 \mathrm{H}), 2.15(\mathrm{~s}, 6 \mathrm{H}) ;{ }^{31} \mathrm{P}\{1 \mathrm{H}\} \mathrm{NMR}\left(162 \mathrm{MHz}, \mathrm{CD}_{3} \mathrm{CN}\right):-27.8 ;{ }^{13} \mathrm{C}$ $\{1 \mathrm{H}\}$ NMR (100 MHz, CD ${ }_{3} \mathrm{CN}$ ): $\delta 161.7$ (d, J= $\left.9.1 \mathrm{~Hz}\right), 152.0$ (d, J= 19.8 $\mathrm{Hz}), 135.5(\mathrm{~s}), 134.8(\mathrm{~d}, J=3.9 \mathrm{~Hz}), 132.6(\mathrm{~s}), 130.8(\mathrm{~s}), 130.3(\mathrm{~d}, J=4.2$ $\mathrm{Hz}), 130.2(\mathrm{~d}, J=30.8 \mathrm{~Hz}), 128.6(\mathrm{~d}, J=6.6 \mathrm{~Hz}), 121.7(\mathrm{~d}, J=6.1 \mathrm{~Hz})$, $120.7(\mathrm{~d}, J=35 \mathrm{~Hz}), 111.9(\mathrm{~d}, J=3.5 \mathrm{~Hz}), 56.2$ (s). Elemental analysis for $\mathrm{Cu}-3.1 \mathrm{CH}_{3} \mathrm{CN}$, theoretical: $\mathrm{C}, 52.47, \mathrm{H}, 4.31, \mathrm{~N}, 3.99, \mathrm{~S}, 6.09$, measured: $\mathrm{C}, 52.15, \mathrm{H}, 4.10, \mathrm{~N}, 3.77, \mathrm{~S}, 5.74$.

\section{Synthesis of $\mathrm{Cu}-4$}

\{tert-Butyl-4-Me-phenylphosphino\}benzenesulfonic acid L3-H (100 $\mathrm{mg}, 0.29 \mathrm{mmol})$ and $\mathrm{Cu}_{2} \mathrm{O}(22 \mathrm{mg}, 0.15 \mathrm{mmol})$ were added in a Schlenk tube under an atmosphere of argon followed by the slow 
addition of degassed methanol under stirring. Then, the resulting mixture was stirred for one hour at room temperature. The white precipitate was dissolved by the addition of methanol and moderate heating followed by cannulation. The resulting solution was concentrated to give air sensitive colorless crystals of Cu-4 $(71 \mathrm{mg}$, 52\%). ${ }^{1} \mathrm{H}$ NMR (400 MHz, CD ${ }_{3} \mathrm{OD}$ ): $\delta 8.12$ (ddd, $J=8.1,4.3 \mathrm{~Hz}, 1 \mathrm{H}$ ) 7.66-7.62 (m, $1 \mathrm{H}), 7.55$ (ddd, $J=10.1,6.3,3.4 \mathrm{~Hz}, 2 \mathrm{H}), 7.43-7.34(\mathrm{~m}$, 4H), $3.35(\mathrm{~s}, 6 \mathrm{H}), 2.42(\mathrm{~s}, 3 \mathrm{H}), 1.33(\mathrm{~d}, J=15.5 \mathrm{~Hz}, 9 \mathrm{H}) ;{ }^{31} \mathrm{P}\{1 \mathrm{H}\} \mathrm{NMR}$ (162 $\mathrm{MHz}, \mathrm{CD}_{3} \mathrm{OD}$ ): -14.15. Elemental analysis for $\mathrm{Cu}-4.2 \mathrm{CH}_{3} \mathrm{OH}$, theoretical: C, 47.85, H, 6.88, S, 6.08, measured: C, 47.64, H, 5.33, S, 7.06 .

\section{Synthesis of Cu-5}

\{tert-Butyl-phenylphosphino\}benzenesulfonic acid L4-H (100 mg, 0.3 $\mathrm{mmol}$ ) and $\mathrm{Cu}_{2} \mathrm{O}(22 \mathrm{mg}, 0.15 \mathrm{mmol}$ ) were added in a Schlenk tube under an atmosphere of argon followed by the slow addition of degassed methanol under stirring. Then, the resulting mixture was stirred for one hour at room temperature. The white precipitate was dissolved by the addition of methanol followed by cannulation and evaporated under vacuum at $60^{\circ} \mathrm{C}$ to yield a white precipitate. Addition of acetonitrile followed by concentration afforded colorless crystals of Cu-5 dimer (60 mg, 45\%). ${ }^{1} \mathrm{H}$ NMR (400 MHz, $\left.\mathrm{CD}_{3} \mathrm{CN}\right)$ : $\delta$ 8.17-8.13 (m, 1H), 7.85-7.82 (m, 1H), 7.54-7.44 (m, 4H), 7.37-7.36 (m, 3H), $2.18(\mathrm{~s}, 3 \mathrm{H}), 1.28(\mathrm{~d}, J=15 \mathrm{~Hz}, 9 \mathrm{H}) ;{ }^{31} \mathrm{P}\{1 \mathrm{H}\} \mathrm{NMR}(162 \mathrm{MHz}$, $\left.\mathrm{CD}_{3} \mathrm{CN}\right): 8.06 ;{ }^{13} \mathrm{C}\{1 \mathrm{H}\}$ NMR $\left(100 \mathrm{MHz}, \mathrm{CD}_{3} \mathrm{CN}\right): \delta 152.9(\mathrm{~d}, J=17.6$ $\mathrm{Hz}), 135.8$ (s), 134.6 (s), 134.2 (d, J=14 Hz), 130.9 (s), 130.1, 130.0, 129.9, 129.9, 129.6 (d, J=6.3 Hz), 128.9 (d, J= 9.2 Hz), 32.7 (d, J=15.1 $\mathrm{Hz}$ ), 29.0 (d, $J=10.6 \mathrm{~Hz}$ ). Elemental analysis for $\mathrm{Cu}-5$, theoretical: $\mathrm{C}$, 50.76, H, 4.97, N, 3.29, S, 7.53, measured: C, 50.87, H, 4.97, N, 3.22, S, 7.26 .

\section{Synthesis of Cu- 6}

To a Schlenk tube, Cu-1 dimer (45 mg, $0.05 \mathrm{mmol}$ ) was added to methanol mixture $(3 \mathrm{~mL})$ containing $\mathrm{KI}(27 \mathrm{mg}, 0.16 \mathrm{mmol})$ and the resulting was stirred vigorously until the apparition of a white precipate of Cu- $\mathbf{6}$ polymer. The solution was quickly removed by cannulation and the white precipitate was dried under vacuum (59 $\mathrm{mg}, 80 \%) .{ }^{1} \mathrm{H}$ NMR (400 MHz, DMSO-d6): $\delta 8.00$ (d, $J=7.7 \mathrm{~Hz}, 1 \mathrm{H}$ ), $7.52(\mathrm{t}, J=7.6 \mathrm{~Hz}, 1 \mathrm{H}), 7.43-7.28(\mathrm{~m}, 11 \mathrm{H}), 6.93(\mathrm{~s}, 1 \mathrm{H}), 4.09$ (q, J=5.3 $\mathrm{Hz}, 2 \mathrm{H}), 3.17$ (d, J=5.3 Hz, 6H); ${ }^{31} \mathrm{P}\{1 \mathrm{H}\}$ NMR (162 MHz, DMSO-d6): $\delta-11.67 ;{ }^{13} \mathrm{C}\{1 \mathrm{H}\}$ NMR (100 MHz, DMSO-d6): $\delta$ 150.8-150.2 (m), 134.5-134.3 (m), $133.5(\mathrm{~s}), 133.4(\mathrm{~s}), 133.1-133.0(\mathrm{~m}), 129.9(\mathrm{~s}), 129.7$ (s), 128.4 (s), 127.4-127.3 (m), 48.5 (s). HRMS-ESI: $\left(\mathrm{C}_{18} \mathrm{H}_{14} \mathrm{O}_{3}\right.$ IPSCu) [M-l]': calcd.: $530.87476 \mathrm{~m} / \mathrm{z}$; found: 530.8743 (1 ppm). Elemental analysis for vacuum dried Cu-6, theoretical: C, 29.34, H, 1.92, S, 4.35, measured: C, 29.15; H, 2.04; S, 4.05 .

\section{Synthesis of $\mathrm{Cu}-7$}

Murray's ligand \{diphenylphosphino\}benzenesulfonic acid L1-H (66.5 $\mathrm{mg}, 0.2 \mathrm{mmol}$ ) and $t$-BuOK $(23 \mathrm{mg}, 0.2 \mathrm{mmol}$ ) were added in a Schlenk tube under an atmosphere of argon followed by the slow addition of degassed methanol. Then, the resulting mixture was stirred for half hour at room temperature followed by the addition of Cu-1 dimer ( $85 \mathrm{mg}, 0.1 \mathrm{mmol}$ ). The resulting mixture was heated at $60^{\circ} \mathrm{C}$ overnight. After cooling at room temperature, the solution was removed by cannulation and the white precipitate was dried under vacuum to give Cu-7 (136 mg, 90\%). ${ }^{1} \mathrm{H}$ NMR (400 MHz, DMSO- d6): $\delta 8.00(\mathrm{~d}, J=7.7 \mathrm{~Hz}, 2 \mathrm{H}), 7.52(\mathrm{t}, J=7.6 \mathrm{~Hz}, 2 \mathrm{H}), 7.43-7.37(\mathrm{~m}, 8 \mathrm{H})$, 7.31-7.23 (m, 14H), $6.96(\mathrm{~d}, J=7.5 \mathrm{~Hz}, 2 \mathrm{H}) ;{ }^{31 \mathrm{P}}\{1 \mathrm{H}\} \mathrm{NMR}(162 \mathrm{MHz}$, DMSO-d6): $\delta-11.68 ;{ }^{13} \mathrm{C}\{1 \mathrm{H}\}$ NMR (100 MHz, DMSO-d6): $\delta 150.8$ (d, J=6.5 Hz), 134.2 (s), 133.5 (s), 133.2 (d, J=1.9 Hz), 129.8 (s), 129.6 (s), 128.3 (s), 127.3 (s). Elemental analysis for $\mathrm{Cu}-7.1 \mathrm{CH}_{3} \mathrm{OH}$., theoretical: C, 54.37, H, 3.95, S, 7.84, measured: C, 54.49, H, 3.51, S, 7.76 .

\section{Notes and references}

1 (a) S. Boudin, J. Chim. Physique, 1930, 27, 285; (b) G. N. Lewis, D. Lipkin and T. T. Magel, J. Am. Chem. Soc., 1941, 63, 3005; (c) C. A. Parker and C. G. Hatchard, Trans. Faraday Soc., 1961,57, 1894; (d) Z. Yang, Z. Mao, Z. Xie, Y. Zhang, S. Liu, J. Zhao, J. Xu, Z. Chi and M. P. Aldred, Chem. Soc. Rev., 2017, 46, 915.

2 J. R. Kirchhoff, R. E. Gamache Jr., M. W. Blaskie, A. A. Del Paggio, R. K. Lengel and D. R. McMillin, Inorg. Chem., 1983, 22, 2380.

3 (a) H. Yersin, A. F. Rausch, R. Czerwienic, T. Hofbeck and T. Fischer, Coord. Chem. Rev., 2011, 255, 2622; (b) V. W.-W. Yam, V. K.-M. Au and S. Y.-L. Leung, Chem. Rev., 2015, 115, 7589 ; (c) E. Cariati, E. Lucenti, C. Botta, U. Giovanella, D. Marinotto and S. Righetto, Coord. Chem. Rev., 2016, 306, 566. (d) Y. Liu, S.-C. Yiu, C.-L. Ho and W.-Y. Wong, Coord. Chem. Rev., doi.org/10.1016/j.ccr.2018.05.010; (e) C. Bizzari, E. Spuling, D. M. Knoll, D. Volz and S. Bräse, Coord. Chem. Rev., doi.org/10.1016/j.ccr.2017.09.011.

4 G. Cheng, G. K.-M. So, W.-P. To, Y. Chen, C.-C. Kwok, C. Ma, X. Guan, X. Chang, W.-M. Kwok and C.-M. Che, Chem. Sci., 2015, 6, 4623.

5 (a) G. Kang, Y. Jeon, K. Y. Lee, J. Kim and T. H. Kim, Cryst. Growth Des., 2015, 15, 5183; (b) T. Hasegawa, A. Kobayashi, H. Ohara, M. Yoshida and M. Kato, Inorg. Chem., 2017, 56, 4928.

6 (a) A. Tsuboyama, K. Kuge, M. Furugori, S. Okada, M. Hoshino and K. Ueno, Inorg. Chem., 2007, 46, 1992; (b) H. Araki, K. Tsuge, Y. Sasaki, S. Ishizaka and N. Kitamura, Inorg. Chem., 2007, 46, 10032; (c) A. Stoïanov, C. Gourlaouen, S. Vela and C. Daniel, J. Phys. Chem. A, 2018, 122, 1413.

7 L. Bergmann, G. J. Hedley, T. Baumann, S. Bräse and I. D. W. Samuel, Sci. Adv., 2016, 2, e1500889.

8 (a) C. L. Linfoot, M. J. Leitl, P. Richardson, A. F. Rausch, O. Chepelin, F. J. White, H. Yersin and N. Robertson, Inorg. Chem., 2014, 53, 10854; (b) L.L. Hu, C. Shen, W.-K. Chu, J. Xiang, F. Yu, G. Xiang, Y. Nie, C.-L. Kwok, C.-F. Leung and C.-C. Ko, Polyhedron, 2017, 127, 203.

9 (a) J. Zhang, C. Duan, C. Han, H. Yang, Y. Wei and H. Xu, Adv. Mater., 2016, 28, 5975; (b) C. Zeng, N. Wang, T. Peng and S. Wang, Inorg. Chem., 2017, 56, 1616.

10 (a) K. R. Kyle, C. K. Ryu, J. A. DiBenedetto and P. C. Ford, J. Am. Chem. Soc., 1991, 113, 2954; (b) N. Kitada and T. Ishida, CrystEngComm, 2014, 16, 8035; (c) J. Troyano, J. Perles, P. Amo-Ochoa, J. I. Martínez, M. Concepción Gimeno, V. Fernández-Moreira, F. Zamora and S. Delgado, Chem. Eur. J., 2016, 22, 18027; (d) X.-L. Chen, R. Yu, X.-Y. Wu, D. Liang, J.-H. Jia and C.-Z. Lu, Chem. Commun., 2016, 52, 6288; (e) W. Liu, Y. Fang and J. Li, Adv. Funct. Mater., 2018, 28, 1705593; (f) X. Zhang, W. Liu, G. Z. Wei, D. Banerjee, Z. Hu and J. Li, J. Am. Chem. Soc., 2014, 136, 14230.

11 (a) V. A. Krylova, P. I. Djurovich, M. T. Whited and M. E. Thompson, Chem. Commun., 2010, 46, 6696; (b) S. Shi, L. R. Collins, M. F. Mahon, P. I. Djurovich, M. E. Thompson and M. K. Whittlesey, Dalton Trans., 2017, 46, 745; (c) M. Gernert, U. Müller, M. Haehnel, J. Pflaum and A. Steffen, Chem. Eur. J., 2017, 23, 2206; (d) A. S. Romanov, C. R. Becker, C. E. James, D. Di, D. Credgington, M. Linnolahti and M. Bochmann, Chem. Eur. J., 2017, 23, 4625.

12 (a) J.-K. Cheng, Y.-G. Yao, J. Zhang, Z.-J. Li, Z.-W. Cai, X.-Y. Zhang, Z.-N. Chen, Y.-B. Chen, Y. Kang, Y.-Y. Qin and Y.-H. Wen, J. Am. Chem. Soc., 2004, 126, 7796; (b) J.-J. Zhao, X. Zhang, Y.-N. Wang, H.-L. Jia, J.-H. Yu and J.-Q. Xu, J. Solid State Chem., 2013, 207, 152; (c) X. Liu, G.-C. Guo, A.-Q. Wu, L.-Z. Cai and J.-S. Huang, Inorg. Chem., 2005, 44, 4282; (d) S. Maderlehner, M. J. Leitl, H. Yersin and A. Pfitzner, Dalton Trans., 2015, 44, 19305. 
13 (a) D. Cortecchia, H. A. Dewi, J. Yin, A. Bruno, S. Chen, T. Baikie, P. P. Boix, M. Grätzel, S. Mhaisalkar, C. Soci and N. Mathews, Inorg. Chem., 2016, 55, 1044 ; (b) Gomez, S.; Urra, I.; Valiente, R.; Rodriguez, F. J. Phys. Condens. Mat., 2010, 22, 295505

14 (a) F. Vazart, P. Savel, C. Latouche, V. Barone, F. Camerel, T. Roisnel, J.-L. Fillaut,H. Akdas-Kilig and M. Achard, Dalton Trans., 2016, 45, 6566; (b) H. Lauwick, Y. Sun, H. Akdas-Kiliç, S. Dérien and M. Achard, Chem. Eur. J., 2018, 24, 7964.

15 E. Drent, R. van Dijk, R. van Ginkel, B. van Oort and R. I. Pugh, Chem. Comm., 2002, 744

16 B. Sundararaju, Z. Tang, M. Achard, G.V. M. Sharma and C. Bruneau, Adv. Synth. Catal., 2010, 352, 3141.

17 M. Osawa, Chem. Commun., 2014, 50, 1801.

18 Y.-E. Kim, J. Kim, J. Woo Park, K. Park and Y. Lee, Chem. Commun., 2017, 53, 2858.

19 A. Kobayashi, R. Arata, T. Ogawa, M. Yoshida and M. Kato, Inorg. Chem., 2017, 56, 4280.

20 A.D. Becke, J. Chem. Phys. 1993, 98, 5648.

21 J.P. Perdew, Phys. Rev. B 1986, 33, 8822.

22 J.P. Perdew, K. Burke, Y. Wang. Phys. Rev. B 1996, 54, 16533.

23 T.H. Dunning Jr., P.J.Hay, In Methods of Electronic Structure Theory SE - 1; Schaefer III, H., Ed.; Modern Theoretical Chemistry; Springer US, 1977; Vol. 3, pp 1-27.

24 M. J. Frisch, G. W. Trucks, H. B. Schlegel, G. E. Scuseria, M. A. Robb, J. R. Cheeseman, G. Scalmani, V. Barone, B. Mennucci and G. A. Petersson, Gaussian09, 2015.

25 V. Barone, M. Cossi, J. Tomasi, J. Chem. Phys. 1997, 107, 3210.

26 T. Yanai, D. P. Tew and N. C. Handy, Chem. Phys. Lett. 2004, 393, 51.

27 a) Y.-J. Li, Z.-Y. Deng, X.-F. Xu, H.-B. Wu, Z.-X. Cao and Q.-M. Wang, Chem. Commun., 2011, 47, 9179; b) O. S. Wenger, Chem. Rev., 2013, 113, 3686.

28 (a) Q. Benito, I. Maurin, M. Poggi, C. Martineau-Corcos, T. Gacoin, J.P. Boilot and S. Perruchas, J. Mater. Chem. C., 2016, 4, 11231; (b) A. Kobayashi, Y. Yoshida, M. Yoshida and M. Kato, Chem. Eur. J., 2018, Chem. Eur. J. 10.1002/chem.201802532.

29 A. Schinabeck, M. J. Leitl and H. Yersin, J. Phys. Chem. Lett., 2018, 9, 2848. 